\title{
PENGGUNAAN MEDIA KARTU GAMBAR UNTUK MENINGKATKAN HASIL BELAJAR EKONOMI DI SMP
}

\author{
Dewi Pratita \\ Fakulltas Keguruan dan Ilmu Pendidikan, Universitas Sriwijaya \\ E-mail: dwpratita@gmail.com
}

\begin{abstract}
This study aims to determine the influence of the media card to the students' pictures on subjects of Integrated Social Sciences (Economics). Methods of research using experimental research approach. The population in this study consists of 8 classes with the number of students as many as 304 students. Samples taken as many as 80 people by using a cluster sampling. Methods of data collection by using the tests and observations with a test data analysis techniques to find the average student test results and observation data analysis techniques using the t-test to test the hypothesis. The test results indicate a mean difference between experimental class with a grade of $8.35 \%$ of control. This means there is a picture card media influence the implementation of the increase in student learning outcomes. The results of analysis of observational data shows an increase of activity in learning.
\end{abstract}

Keywords: Media Picture Cards, Student Learning Outcomes

\begin{abstract}
Abstrak
Penelitian ini bertujuan untuk mengetahui pengaruh media kartu gambar terhadap hasil belajar siswa pada mata pelajaran Ilmu Pengetahuan Sosial Terpadu (Ekonomi). Metode penelitian dengan menggunakan pendekatan penelitian eksperimen. Populasi dalam penelitian ini terdiri dari 8 kelas dengan jumlah siswa sebanyak 304 orang siswa. Sampel yang diambil sebanyak 80 orang dengan menggunakan cluster sampling. Metode pengumpulan data dengan menggunakan tes dan observasi dengan teknik analisis data tes berupa mencari rata-rata hasil tes belajar siswa dan teknik analisis data observasi mengunakan uji-t untuk menguji hipotesis. Hasil uji menunjukkan adanya perbedaan mean antara kelas eksperimen dengan kelas kontrol sebesar $8,35 \%$. Hal ini berarti ada pengaruh penerapan media kartu gambar terhadap peningkatan hasil belajar siswa. Hasil analisis data observasi menunjukkan adanya peningkatan keaktifan siswa dalam belajar.
\end{abstract}

Kata kunci : Media Kartu Gambar, Hasil Belajar Siswa

\section{PENDAHULUAN}

Proses pembelajaran merupakan bagi-an yang paling pokok dalam kegiatan pendi-dikan di sekolah. Pembelajaran merupakan interaksi timbal balik antara peserta didik dengan guru dan antar sesama peserta didik dalam proses pembelajaran. Pengertian inter-aksi mengandung unsur saling memberi dan menerima. Gondo (2007:1) mengemukakan dalam setiap interaksi pembelajaran ditandai sejumlah unsur yaitu (1) tujuan yang hendak dicapai, (2) siswa dan guru, (3) bahan pelajaran, (4) metode yang digunakan untuk menciptakan situasi pembelajaran dan (5) penilaian yang fungsinya untuk menetapkan seberapa jauh ketercapaian tujuan belajar.

Pembelajaran pada dasarnya merupakan upaya untuk mengarahkan peserta didik ke dalam proses belajar sehingga mereka dapat memperoleh tujuan belajar sesuai dengan apa yang diharapkan. Pembelajaran hendaknya memperhatikan kondisi individu peserta didik karena merekalah yang akan belajar. Peserta didik merupakan individu yang berbeda-beda satu sama lain, memiliki keunikan masing-masing yang tidak sama. 
Oleh karena itu pembelajaran hendak-nya memperhatikan perbedaanperbedaan in-dividual tersebut, sehingga pembelajaran be-nar-benar dapat merubah kondisi peserta didik dari yang tidak tahu menjadi tahu serta dari yang berperilaku kurang baik menjadi baik. Kondisi riil peserta didik yang seperti ini, kadang-kadang kurang mendapat perhatian di kalangan guru. Hal ini terlihat dari perhatian sebagian guru yang cenderung memperhati-kan kelas secara keseluruhan, tidak perorang-an atau kelompok peserta didik, sehingga perbedaan individual kurang mendapat perhatian. Gejala lain yang terlihat pada kenyataan banyaknya guru yang mengguna-kan metode pengajaran yang cenderung sama setiap kali pertemuan di kelas berlangsung.

Pembelajaran yang kurang memperha-tikan perbedaan individual peserta didik, akan sulit untuk dapat mengantarkan peserta didik ke arah pencapaian tujuan pembelajaran. Kondisi seperti inilah yang pada umumnya terjadi pada pembelajaran konvensional. Konsekuensi dari pendekatan pembelajaran seperti ini adalah terjadinya kesenjangan yang nyata antara peserta didik yang cerdas dan peserta didik yang kurang cerdas dalam pencapaian tujuan pembelajaran.

Beberapa penelitian membuktikan bahwa perhatian peserta didik berkurang bersamaan dengan berlalunya waktu. Hartono (2007:3) mengemukakan penelitian yang dilakukan McKeachie menyebutkan bahwa dalam sepuluh menit pertama perhatian siswa dapat mencapai $70 \%$, dan berkurang sampai menjadi $20 \%$ pada waktu 20 menit terakhir. Kondisi tersebut merupakan kondisi umum yang sering terjadi di lingkungan sekolah. Hal ini menyebabkan seringnya terjadi kegagalan dalam dunia pendidikan terutama disebabkan peserta didik di ruang kelas lebih banyak menggunakan indera pendengarannya, dibandingkan visual, sehingga apa yang dipelajari di kelas tersebut cenderung untuk dilupakan.
Dalam interaksi belajar mengajar dite-mukan bahwa proses pembelajaran yang dila-kukan oleh peserta didik merupakan kunci keberhasilan belajar. Proses belajar merupa-kan aktivitas psikis berkenaan dengan bahan belajar. Aktivitas mempelajari bahan belajar tersebut memakan waktu. Lama waktu mempelajari tergantung pada jenis dan sifat bahan belajar. Selain itu lama waktu mempe-lajari juga tergantung pada kemampuan peser-ta didik. Jika bahan belajarnya sukar dan peserta didik kurang mampu maka dapat diduga bahwa proses belajar memakan waktu yang lama.

Sebaliknya, jika bahan belajar mudah dan peserta didik berkemampuan tinggi maka proses belajar memakan waktu singkat. Akti-vitas belajar tersebut juga dapat diketahui oleh guru dari perlakuan peserta didik terha-dap bahan belajar. Proses belajar sesuatu dialami oleh peserta didik dan aktivitas belajar sesuatu dapat diamati oleh guru.

Proses belajar merupakan hal yang kompleks. Siswalah yang menentukan terjadi atau tidak terjadi proses belajar. Untuk melakukan proses belajar siswa menghadapi masalah-masalah secara intern. Jika siswa tidak dapat mengatasi masalahnya, maka ia tidak belajar dengan baik.

Dimyati dan Mudjiono (2002:239) mengatakan bahwa salah satu masalah yang dihadapi siswa dalam belajar yaitu konsentrasi belajar siswa yang merupakan kemampuan memusatkan perhatian pada pelajaran. Pemusatan perhatian tersebut tertuju pada isi bahan belajar maupun proses memperolehnya.

Dalam proses pembelajaran tidak semua bahan belajar dapat dipahami oleh peserta didik pada saat terjadinya proses pem-belajaran. Silberman (dalam Hartono, 2007:4) mengemukakan bahwa:

a. Apa yang saya dengar, saya lupa

b. Apa yang saya dengar dan lihat, saya ingat sedikit 
c. Apa yang saya dengar, lihat, dan tanyakan atau didiskusikan dengan beberapa teman lain, saya mulai paham

d. Apa yang saya dengar, lihat, didiskusikan dan lakukan, saya memperoleh pengetahu-an dan keterampilan

Ada beberapa alasan yang dikemukakan mengenai penyebab mengapa kebanyakan orang cenderung melupakan apa yang mereka dengar. Salah satu jawaban yang menarik adalah karena adanya perbedaan antara kece-patan bicara guru dengan tingkat kemampuan peserta didik mendengarkan apa yang disam-paikan guru. Kebanyakan guru berbicara seki-tar 100-200 kata per menit, sementara peserta didik hanya mampu mendengarkan 50-100 kata per menitnya atau setengah dari apa yang dikemukakan guru, karena peserta didik men-dengarkan pembicaraan guru sambil berfikir.

Kerja otak manusia tidak sama dengan tape recorder yang mampu merekam suara sebanyak apa yang diucapkan dengan waktu yang sama pada saat pengucapan. Otak ma-nusia selalu mempertanyakan informasi yang masuk ke dalamnya, dan otak juga memproses setiap informasi yang diterima, sehing-ga perhatian tidak dapat tertuju pada stimulus secara menyeluruh. Hal ini menyebabkan tidak semua yang dipelajari dapat diingat dengan baik. Penambahan visual pada proses pembelajaran dapat menaikkan ingatan sam-pai $171 \%$ dari ingatan semula.

Dengan penambahan visual di samping auditori dalam pembelajaran kesan yang masuk dalam diri peserta didik semakin kuat sehingga dapat bertahan lebih lama diban-dingkan dengan hanya menggunakan audio atau pendengaran saja. Hal ini karena fungsi sensasi perhatian yang dimiliki peserta didik saling menguatkan, apa yang didengar dikuat-kan oleh penglihatan atau visual, dan apa yang dilihat dikuatkan oleh audio atau pende-ngaran. Dalam arti kata pembelajaran seperti ini sangat membantu bagi pemahaman peserta didik terhadap materi pembelajaran.

Proses pembelajaran pada dasarnya merupakan pemberian stimulus-stimulus kepada peserta didik, agar terjadinya respons yang positif pada diri peserta didik. Kesediaan dan kesiapan peserta didik dalam mengikuti setiap proses pembelajaran akan mampu me-nimbulkan respons yang baik terhadap stimulus yang diterima peserta didik dalam proses pembelajaran. Respons akan menjadi kuat jika stimulusnya juga kuat. Ulangan-ulangan terhadap stimulus dapat memperlan-car hubungan antara stimulus dan respons, sehingga respons yang ditimbulkan akan menjadi kuat. Hal ini akan memberikan kesan yang kuat pula pada diri peserta didik, sehingga mereka akan mampu mempertahan-kan respons tersebut dalam ingatannya.

Hubungan antara stimulus dan respons akan menjadi lebih baik jika dapat menghasil-kan hal-hal yang menyenangkan. Efek me-nyenangkan yang ditimbulkan stimulus akan mampu memberi kesan yang mendalam pada diri peserta didik, sehingga mereka cenderung akan mengulang aktivitas tersebut. Hal ini dapat mengakibatkan peserta didik mampu mempertahankan stimulus dalam ingatan mereka dalam waktu yang lama, sehingga peserta didik mampu mengulangi apa yang mereka peroleh dalam pembelajaran.

Stimulus yang digunakan dalam proses pembelajaran dapat berupa pemilihan metode dan media pembelajaran yang tepat. Pemilihan dan penggunaan metode dalam proses pembelajaran tidak terlepas dari penggunaan media. Bisa saja penggunaan metodenya sudah tepat, tetapi media yang digunakan tidak menunjang metode tersebut atau sama sekali tidak adanya media sebagai penunjang dalam belajar. Penggunaan media dalam proses pembelajaran dapat meningkat-kan motivasi belajar peserta didik.

Menurut Harjanto (2005:244) penggu-naan media pendidikan dapat mempertinggi proses dan hasil pembelajaran 
adalah berke-naan dengan taraf berpikir siswa. Taraf ber-pikir manusia mengikuti tahap perkembangan. Dimulai dari berpikir abstrak menuju ke berpikir konkret, dimulai dari berpikir seder-hana menuju ke berpikir kompleks. Penggu-naan media pendidikan erat kaitannya dengan tahapan berpikir tersebut sebab melalui media pendidikan halhal yang abstrak dapat dikonkretkan dan halhal yang kompleks da-pat disederhanakan.

Dalam kenyataan yang terjadi di SMP Negeri 9 Palembang dan sekolahsekolah pa-da umumnya, guru terkadang mengalami ke-sulitan pada saat menjelaskan pelajaran, tenaga hampir terkuras, waktu lebih banyak digunakan dan suara pun hampir hilang dari tenggorokan tetapi peserta didik masih sulit untuk menerima materi pelajaran yang telah diterangkan guru. Lalu guru pun berfikir siapakah yang salah dalam proses pembelajar-an itu. Guru ataukah peserta didiknya ? Terlepas dari siapa yang salah, keadaan seperti inilah yang menjadi penghambat baik dalam diri guru maupun peserta didik sewaktu menyampaikan pesan maupun menerima pesan, proses komunikasi belajar mengajar sering kali berlangsung secara tidak efektif dan efisien.

Setelah peneliti mengadakan studi pendahuluan di SMP N 9 Palembang diketahui bahwa metode yang digunakan guru cukup bervariasi. Metode yang digunakan yaitu ceramah, tanya jawab, diskusi dan pemberian tugas. Namun dalam pelaksanaanya, peserta didik masih kurang aktif dalam proses pem-belajaran. Hal ini disebabkan guru kurang me-libatkan peserta didik, peserta didik dibiasa-kan pasif dan menunggu apapun yang diberi-kan oleh guru. Untuk itu diperlukan tantangan bagi peserta didik untuk terlibat langsung da-lam proses pembelajaran.

Selain metode, dari dalam diri peserta didik juga kurang inisiatif dalam belajar. Menurut guru, peserta didik harus dipancing terlebih dahulu untuk aktif dalam kegiatan pembelajaran. Hal ini dapat dilihat dari kurangnya persiapan peserta didik dalam mengikuti pelajaran. Peserta didik cenderung malas membaca buku dirumah sebelum materi di-sampaikan. Selain itu kurangnya penguatan (reinforcement) dari dalam diri peserta didik, peserta didik jarang sekali mengulang pelajar-an yang baru diterimanya disekolah untuk di-pelajari dirumah. Hal ini terlihat ketika guru menanyakan kembali materi yang telah disampaikannya ketika melakukan apersepsi pada pertemuan berikutnya, peserta didik se-ring lupa bila tidak diingatkan oleh guru dan baru belajar bila ada ulangan.

Untuk mengatasi hambatan seperti ini-lah maka guru dituntut untuk aktif dan kreatif bukan hanya pada saat merancang tetapi juga mampu menerapkannya dalam proses pem-belajaran dan peserta didik juga harus dili-batkan sehingga hasil belajar peserta didik berada pada tingkat yang optimal. Salah satu cara yang dapat digunakan oleh guru dalam mengatasi hambatan seperti ini adalah peng-gunaan media sebagai alat bantu mengajar.

Media yang dikembangkan harus dapat merangsang pikiran, perasaan, minat serta perhatian peserta didik sedemikian rupa sehingga terjadi proses belajar yang efektif dan efisien. Dengan menggunakan media pembe-lajaran, dapat diatasi sikap pasif peserta didik. Dalam hal ini, media berguna untuk menimbulkan gairah belajar, memungkinkan interaksi yang baik antara peserta didik dan lingkungan, memungkinkan peserta didik belajar sendiri menurut kemampuan dan minatnya. Salah satu media yang dapat digunakan adalah media kartu gambar.

Tujuan dari penelitian ini adalah untuk meningkatkan hasil belajar siswa melalui penerapan media kartu gambar serta diharap-kan terjadi peningkatan keaktifan dalam pro-ses pembelajaran siswa.

\section{METODOLOGI PENELITIAN}

Penelitian ini bertujuan untuk melihat pengaruh penerapan media kartu gambar terhadap hasil belajar siswa. 
Penelitian ini merupakan penelitian eksperimen yang meli-batkan kelas eksperimen dan kelas kontrol. Sebanyak 40 siswa terlibat dalam kelas eks-perimen dan 40 siswa terlibat dalam kelas kontrol. Pada kelas eksperimen diterapkan pembelajaran ekonomi dengan menggunakan media kartu gambar dan pada kelas kontrol pembelajaran ekonomi dilakukan tanpa meng-gunakan media kartu gambar.

Pada saat berlangsung pembelajaran ekonomi di kelas eksperimen dan kelas kontrol peneliti melakukan observasi dan hasilnya dicatat dalam lembar observasi. Data yang diperoleh dalam penelitian ini berupa data kuantitatif dan data kualitatif. Data kuantitatif berupa skor hasil belajar siswa setelah pembelajaran pada ma-singmasing kelompok. Cara menganalisis data tes adalah dengan mencari rerata hasil belajar pada kelas eksperimen dan kelas kontrol dengan men-jumlahkan skor tiap siswa dibagi jumlah siswa.

Kemudian mencari rerata skor keseluruhan yang didapat dari 3 kali pertemuan dengan cara menjumlahkan rerata skor setiap pertemuan dibagi banyaknya pertemuan. Sementara untuk data observasi dianalisis sesuai dengan skor yang didapatkan masingmasing siswa sehingga diketahui tingkat keaktifan siswa selama proses pembelajaran.

\section{HASIL DAN PEMBAHASAN \\ Peningkatan hasil belajar siswa melalui penerapan media kartu gambar}

Untuk mengetahui pengaruh penerap-an media kartu gambar terhadap hasil belajar siswa mata pelajaran Ilmu Pengetahuan Sosial (Ekonomi) digunakan tes. Data didapat mela-lui tes formatif berbentuk soal uraian seba-nyak lima soal yang diberikan pada kelas eksperimen maupun kelas kontrol di setiap akhir perlakuan. Skor hasil penilaian pada da-ta tes untuk kelas eksperimen yakni kelas VII.3 yang berjumlah 40 siswa dan kelas kontrol yakni kelas VII.4 yang berjumlah 40 siswa dapat dilihat pada tabel berikut.

\begin{tabular}{ccccc}
\multicolumn{5}{c}{ Tabel 1 Mean Skor Nilai Tes Kelas Eksperimen dan Kelas Kontrol } \\
\hline Tes & Kelas Eksperimen & Mean & Kelas Kontrol & Mean \\
\hline Pertama & 2965 & 74,12 & 2805 & 70,12 \\
Kedua & 3220 & 80,5 & 3016 & 75,4 \\
Ketiga & 3470 & 86,75 & 3090 & 77,25 \\
\hline
\end{tabular}

Berdasarkan tabel diatas dapat diana-lisis bahwa hasil tes pada pertemuan pertama, kedua, dan ketiga secara keseluruhan rerata skor nilai (mean) siswa kelas eksperimen lebih tinggi dibandingkan dengan rerata skor siswa kelas kontrol, dimana mean kelas eksperimen sebesar 80,5 sedangkan mean pada kelas kontrol sebesar 77,25 berarti selisih mean 6,20 atau terjadi peningkatan hasil belajar siswa sebesar $8,35 \%$.

Melalui penerapan media kartu gambar siswa menjadi lebih aktif, berfikir kritis, berusaha mencari contoh sendiri tentang materi yang sedang dijelaskan oleh guru, menerapkan konsep berupa permainan sehingga tidak terkesan menghafal, dan ketika diberi umpan balik dengan memberikan pertanyaan, siswa dapat menjawab pertanyaan dari guru pada akhirnya berdampak pada peningkatan hasil belajar.

\section{Peningkatan keaktifan siswa melalui hasil observasi}

Data observasi digunakan untuk meli-hat keaktifan siswa pada saat penerapan me-dia kartu gambar pada kelas eksperimen dan tidak diterapkan media kartu gambar pada kelas kontrol .

Keaktifan siswa dalam penerapan me-dia kartu gambar dilihat dari lembar observasi yang telah dipersiapkan, meliputi 4 indikator yaitu keaktifan gerak, keaktifan menulis, ke-aktifan lisan, dan keaktifan 
visual dengan kriteria penilaian sangat aktif, aktif, cukup aktif, kurang aktif dan sangat kurang aktif. Penilaian keaktifan siswa ini dilakukan pada saat proses pembelajaran berlangsung baik pada kelas eksperimen maupun pada kelas kontrol. Observasi ini dilakukan untuk me-ngetahui perubahan keaktifan siswa setelah penerapan media kartu gambar.

\section{Tabel 2. Rekapitulasi Keaktifan Siswa}

\begin{tabular}{lcccccccc}
\hline \multirow{2}{*}{ Indikator } & \multicolumn{3}{c}{ Kelas Eksperimen } & \multicolumn{4}{c}{ Kelas Kontrol } \\
\cline { 2 - 4 } & \multicolumn{3}{c}{ Pertemuan } & & \multicolumn{3}{c}{ Pertemuan } & \multirow{2}{*}{ Rata-rata } \\
\cline { 2 - 4 } \cline { 6 - 8 } & $\mathbf{1}$ & $\mathbf{2}$ & $\mathbf{3}$ & & $\mathbf{1}$ & $\mathbf{2}$ & $\mathbf{3}$ & \\
\hline Keaktifan Gerak & 62 & 66 & 70,5 & 66,16 & 44,5 & 53,5 & 53,5 & 50,5 \\
Keaktifan Menulis & 68,5 & 71 & 74,5 & 71,33 & 39,5 & 49 & 55 & 47,83 \\
Keaktifan Lisan & 59 & 67 & 78 & 68 & 40,5 & 43 & 57 & 46,83 \\
Keaktifan Visual & 73,5 & 75 & 81,5 & 76,66 & 55 & 65,5 & 68 & 62,83 \\
\hline
\end{tabular}

Berdasarkan tabel rekapitulasii keaktifan siswa diatas maka dapat dilihat adanya peningkatan rata-rata keaktifan gerak, menulis, lisan dan keaktifan visual pada kelas eksperimen dan kelas kontrol. Penerapan media kartu gambar dalam pembelajaran ekonomi di kelas akan meningkatkan keaktifan siswa dalam gerak, menulis, lisan dan visual.

\section{Media Kartu Gambar}

Proses pembelajaran merupakan suatu kegiatan melaksanakan kurikulum suatu lem-baga pendidikan agar dapat mempenga-ruhi para peserta didik mencapai tujuan pendidik-an yang telah ditetapkan. Tujuan pendidikan pada dasarnya mengantarkan para peserta didik menuju pada perubahan-perubahan tingkah laku baik intelektual, moral maupun sosial agar dapat hidup mandiri sebagai individu dan mahluk sosial. Dalam mencapai tujuan tersebut peserta didik berinteraksi de-ngan lingkungan belajar yang diatur guru melalui proses pembelajaran.

Lingkungan belajar yang diatur oleh guru mencakup tujuan pengajaran, bahan pengajaran, metodologi pengajaran dan penilaian pengajaran. Unsur-unsur tersebut biasa dikenal dengan komponen-komponen penga-jaran. Tujuan pengajaran adalah rumusan kemampuan yang diharapkan dimiliki para peserta didik setelah selesai menempuh berba-gai pengalaman belajarnya pada akhir proses pembelajaran.

Bahan pengajaran adalah seperangkat materi keilmuan yang terdiri atas fakta, kon-sep, prinsip, generalisasi suatu ilmu pengeta-huan yang bersumber dari kurikulum dan dapat menunjang tercapainya tujuan pembela-jaran. Metodologi pengajaran adalah metode dan teknik yang digunakan guru dalam melakukan interaksinya dengan peserta didik agar bahan pengajaran sampai kepada peserta didik sehingga peserta didik menguasai tujuan pembelajaran.

Dalam metodologi pengajaran ada dua aspek yang paling menonjol yakni metode mengajar dan media pengajaran sebagai alat bantu mengajar. Sedangkan penilaian adalah alat untuk mengukur atau menentukan taraf tercapai tidaknya tujuan pembelajaran. Jadi dapat disimpulkan bahwa kedudukan media sebagai alat bantu mengajar ada dalam komponen metodologi, sebagai salah satu lingkungan belajar yang diatur oleh guru.

Asnawir (2002:12) mengemukakan bahwa media pengajaran adalah sesuatu yang bersifat menyalurkan pesan dan dapat merangsang berfikir, perasaan dan kemauan siswa sehingga dapat mendorong terjadinya proses belajar dalam dirinya. Penggunaan media secara kreatif akan memungkinkan siswa untuk belajar lebih baik dan dapat 
meningkatkan kemampuan mereka sesuai dengan tujuan yang ingin dicapai.

Menurut Sadiman (2003:6) media pengajaran adalah segala sesuatu yang dapat digunakan untuk menyalurkan pesan dari pengirim ke penerima sehingga dapat merangsang pikiran, perasaan, perhatian dan minat siswa sedemikian rupa sehingga terjadi proses belajar.

Sementara menurut Arsyad (2004:3) mengemukakan bahwa media pengajaran ada-lah manusia, materi atau kejadian yang mem-buat siswa mampu memperoleh pengetahuan, keterampilan dan sikap dan bersifat menyusun kembali informasi visual ataupun verbal.

Dari beberapa pendapat para ahli diatas dapat ditarik kesimpulan bahwa media pengajaran merupakan semua bentuk perantara yang digunakan untuk menyalurkan pesan dari pengirim ke penerima ataupun sebaliknya yang dapat merangsang pikiran, perasaan, perhatian dan minat siswa dalam suatu proses pembelajaran

Media kartu gambar termasuk dalam media grafis dan media visual. Sebagaimana halnya media yang lain, media grafis berfungsi untuk menyalurkan pesan dari sumber ke penerima pesan. Salurannya yang dipakai menyangkut indera penglihatan. Pesan yang akan disampaikan dituangkan kedalam simbol-simbol komunikasi visual (Sadiman, 2005: 28). Simbol-simbol tersebut perlu dipa-hami benar artinya agar proses penyampaian pesan dapat berhasil dan efisien. Selain fungsi umum tersebut, secara khusus grafis berfungsi pula untuk menarik perhatian, memperjelas sajian ide, mengilustrasikan atau menghiasi fakta yang mungkin akan cepat dilupakan atau diabaikan bila tidak digrafiskan.

Menurut Harjanto (2005:237) media grafis sering juga disebut media dua dimensi, yakni media yang mempunyai ukuran panjang dan lebar.

Selain sederhana dan mudah membuatnya media grafis termasuk media yang relatif murah ditinjau dari segi biayanya. Ba- nyak jenis media grafis, salah satu di antaranya yaitu media kartu.

Menurut Gondo (2007:3) media kartu dapat meliputi: (1) kartu huruf atau abjad, (2) kartu kata, (3) kartu kalimat, dan (4) kartu gambar. Dalam penelitian ini digunakan jenis media kartu gambar, kartu ini diciptakan dengan tujuan untuk menarik perhatian dan minat siswa untuk belajar sehingga dapat mencapai tujuan pembelajaran.

Di antara media pendidikan, gambar adalah media yang paling umum dipakai. Gambar merupakan bahasa yang umum, yang dapat dimengerti dan dinikmati dimana - mana. Media kartu gambar merupakan media yang dibuat dari karton tebal yang dipola berbentuk kartu dan ditempeli gambar yang berhubungan dengan materi pembelajaran (Sadiman, 2005:29).

Menurut Waskito (2007:1) kartu gambar akan lebih memfokuskan siswa didik dalam belajar, dan akan memudahkan guru dalam mengajar karena fokus siswa akan terletak pada gambar yang sedang digunakan guru sebagai media pembelajaran.

Dari berbagai pendapat diatas, maka dapat disimpulkan bahwa media kartu gambar merupakan bagian dari media grafis yaitu media yang mempunyai ukuran panjang dan lebar yang dapat dibuat dari karton tebal yang sudah dipola dengan ukuran panjang $10 \mathrm{~cm}$ dan lebar $5 \mathrm{~cm}$ berbentuk kartu dan ditempeli gambar yang berhubungan dengan materi pelajaran tentang pelaku kegiatan ekonomi (kegiatan produksi, konsumsi dan distribusi barang dan jasa) yang sedang dijelaskan guru dengan harapan peserta didik akan lebih fokus terhadap apa yang sedang dipelajarinya.

\section{Media Kartu Gambar dalam Pembelajaran}

Kartu gambar merupakan salah satu media alternatif yang digunakan dalam proses pembelajaran. Kartu ini diharapkan dapat memotivasi siswa dalam belajar, sehingga berpengaruh pada hasil belajar. 
Kartu ini berukuran panjang $10 \mathrm{~cm}$ dan lebar $5 \mathrm{~cm}$.

Manfaat dari penggunaan media kartu gambar adalah penyampaian dan penjelasan mengenai informasi, pesan, ide dan sebagainya dengan tanpa banyak menggunakan bahasa - bahasa verbal tetapi dapat lebih memberi kesan.

Menurut Sadiman (2005:31) menyebutkan kelebihan dari penggunaan media kartu gambar yaitu:

a. Sifatnya kongkret (lebih realistis menunjukkan pokok masalah disbandingkan dengan media verbal semata)

b. Gambar dapat mengatasi batasan ruang dan waktu

c. Media kartu bergambar dapat memperjelas suatu masalah

d. Media kartu bergambar harganya murah dan mudah didapat serta digunakan tanpa memerlukan peralatan khusus.

Sudjana (2001:71) mengemukakan

kelebihan dalam penggunaan gambar sebagai media dalam proses pembelajaran antara lain:

a. Mudah dimanfaatkan dalam kegiatan pembelajaran karena praktis tanpa memer-lukan perlengkapan apa-apa

b. Harganya relatif lebih murah daripada jenis-jenis media pengajaran lainnya dan cara memperolehnya pun mudah sekali tanpa perlu mengeluarkan biaya. Dengan memanfaatkan kalen-der bekas, majalah, surat kabar dan bahan-bahan grafis lainnya.

c. Gambar bisa dipergunakan dalam banyak hal, untuk berbagai jenjang pengajaran dan berbagai disiplin ilmu. Mulai dari TK sampai Perguruan Tinggi dan dari ilmu-ilmu sosial sampai ilmuilmu eksakta.

d. Gambar dapat menerjemahkan konsep atau gagasan yang abstrak menjadi lebih realistik.

Selain mengemukakan kelebihan dalam penggunaan gambar sebagai media dalam proses pembelajaran, Sudjana (2001:72) juga mengemukakan kelemahan dalam pengguna-an gambar sebagai media dalam proses pem-belajaran, di antaranya yaitu:

a. Beberapa gambarnya sudah cukup mema-dai akan tetapi tidak cukup besar ukuran-nya bila dipergunakan untuk tujuan peng-ajaran kelompok besar, kecuali bilamana diproyeksikan melalui proyektor.

b. Dalam sebuah gambar bagaimanapun indahnya tetap tidak memperlihatkan gerak seperti halnya benda hidup.

Menurut Waskito (2007:2) Gambar yang baik yang dapat ditempel pada media kartu dapat memenuhi beberapa syarat di antaranya:

a. Autentik; gambar tersebut harus secara jujur melukiskan situasi seperti kalau orang melihat benda sebenarnya.

b. Sederhana; komposisi gambar hendaknya cukup jelas menunjukkan poin-poin po-kok dalam gambar.

c. Ukuran relatif (dapat membesarkan atau memperkecil objek atau benda sebenarnya).

d. Gambar yang ditempel tidak hanya menunjukkan objek dalam keadaan diam tapi memperlihatkan aktivitas tertentu.

e. Gambar yang bagus belum tentu baik untuk mencapai tujuan pembelajaran

f. Tidak setiap gambar yang bagus merupakan media yang bagus sebagai media yang baik, gambar hendaklah bagus dari sudut seni dan sesuai dengan tujuan pembelajaran yang ingin dicapai.

James W. Brown (dalam Sudjana dan Rivai, 2001:12) menyatakan tentang bagaima-na siswa belajar melalui gambar yaitu:

a. Ilustrasi gambar merupakan perangkat pengajaran yang dapat menarik minat belajar siswa secara efektif.

b. Ilustrasi gambar merupakan perangkat tingkat abstrak yang dapat ditafsirkan berdasarkan pengalaman dimasa lalu, melalui penafsiran kata-kata.

c. Ilustrasi gambar membantu siswa memba-ca buku pelajaran terutama dalam menaf-sirkan dan mengingat-ingat isi materi teks yang menyertainya. 
d. Ilustrasi gambar isinya harus dikaitkan dengan kehidupan nyata, agar minat siswa menjadi efektif.

e. Ilustrasi gambar hendaknya sedemikian rupa sehingga tidak bertentangan dengan mata pengamat.

Pembelajaran ekonomi selama ini biasa dilakukan dengan metode ceramah dalam hal ini menyebabkan siswa kurang berminat terhadap isi pelajaran sehingga menga-kibatkan hasil belajar yang kurang memuas-kan.

Kartu gambar sebagai media pengajar-an dalam pembelajaran ekonomi dapat diman-faatkan untuk menarik minat dan meningkat-kan motivasi, minat, keaktifan siswa dalam pembelajaran serta dapat mencapai tujuan yang diinginkan sesuai kompetensi yang telah ditetapkan.

\section{PENUTUP}

Dari hasil penelitian ini menunjukkan adanya pengaruh penerapan media kartu gam-bar terhadap hasil belajar siswa. Hal ini ter-bukti dari adanya perbedaan hasil belajar di kelas eksperimen dan kelas kontrol. Keaktifan siswa juga menunjukkan peningkatan di kelas eksperimen yaitu kelas yang mendapatkan perlakuan dengan penerapan media kartu gambar dalam pembelajaran ekonomi.

Dari hasil yang diperoleh dalam pene-litian ini maka kepada guru ekonomi yang mengajar dapat menerapkan penggunaan me-dia kartu gambar dalam pembelajaran ekono-mi agar keaktifan siswa dapat meningkat dan dampaknya diharapkan dapat meningkatkan hasil belajar siswa.

\section{DAFTAR PUSTAKA}

Afgani, W. M. (2009). Pengembangan Media Website Pada Materi Program Linier di Sekolah Menengah Atas. Palembang: Tesis Program Pas-casarjana Universitas Sriwijaya (Tidak Dipublikasikan).

Arsyad, A. (2002). Media Pembelajaran. Jakarta: PT. Raja Grafindo Persada.
Dimyati., \& Mudjiono. (2002). Belajar dan Pembelajaran. Jakarta: PT. Rineka Cipta.

Gondo. (2007). Media Kartu Untuk Pembela-jaran Bahasa Inggris. http:// www. Slb1 Jogya. com/lihat artikel. Php ?id=4. Diakses tanggal 3 November 2007.

Gulo, W. (2004). Srategi Belajar Mengajar. Ja-karta: PT. Grasindo.

Hartono. (2007). Strategi Pembelajaran Active Learning. http:// pagesyourfavorite. com/ppsupi.html. diakses tanggal 11 Desember 2007.

Harjanto. (2005). Perencanaan Pengajaran. Jakarta: PT. Rineka Cipta.

Sadiman, S. dkk. (2003). Interaksi dan Motivasi Belajar Mengajar. Jakarta: Raja Grafindo Persada.

Sadiman, S. dkk. (2005). Media Pendidikan. Jakarta: PT. Raja Grafindo Persada.

Slameto. (2003). Belajar dan Faktor-Faktor yang Mempengaruhinya. Jakarta: Bina Aksara.

Sudjana, N. (2001). Penilaian Hasil Proses Belajar Mengajar. Bandung: Sinar Baru Algensindo.

Sudjana, N., \& Ibrahim. (2001). Penelitian dan Penilaian Pendidikan. Bandung: PT. Sinar Baru Algensindo. 
Jurnal Parameter Volume 25 No. 2 Tahun 2014

DOI : doi.org/10.21009/parameter.252.04

P-ISSN : 0216-261X

Sudjana, N. (2002). Penilaian Hasil Proses Belajar Mengajar. Bandung: Remaja Rosdakarya.
Waskito. (2007). Belajar Bahasa Inggris dengan Kartu (Seri Sayuran). http:// www.wahyumedia.com/kabar_wahy umedia/belajar_bahasa_inggris_den gan_kartu_(seri sayuran).html. Diakses tanggal 4 Desember 2007. 